\title{
Forgotten Soldiers: Burials on the Texas Frontier and Shifting Perceptions of Military Interment
}

Anthony Schienschang II

Department of Anthropology, University of Virginia

Follow this and additional works at: https://scholarworks.sfasu.edu/ita

Part of the American Material Culture Commons, Archaeological Anthropology Commons, Environmental Studies Commons, Other American Studies Commons, Other Arts and Humanities Commons, Other History of Art, Architecture, and Archaeology Commons, and the United States History Commons

Tell us how this article helped you.

This Article is brought to you for free and open access by the Center for Regional Heritage Research at SFA ScholarWorks. It has been accepted for inclusion in Index of Texas Archaeology: Open Access Gray Literature from the Lone Star State by an authorized editor of SFA ScholarWorks. For more information, please contact cdsscholarworks@sfasu.edu. 


\section{Forgotten Soldiers: Burials on the Texas Frontier and Shifting Perceptions of Military Interment}

\section{Licensing Statement}

Reproduction, posting, transmission, or other distribution or use of the Journal volume, individual article or any portion of the material therein, in any medium, is permitted strictly for personal, non-commercial purposes via a personal-use exemption under a Creative Commons license granted by JTAH.org, Inc. This license exemption requires, as a condition of its granted permission, proper credit be attributed to JTAH.org as copyright holder (e.g., Journal of Texas Archeology and History.org @ 2018). No part of this publication may be reproduced, posted, transmitted, or otherwise utilized or distributed in any form by any means or method for commercial purposes without the express written consent of the Publisher. Inquiries should be addressed to JTAH Publisher, Suite 307, Box 361, 5114 Balcones Woods Drive, Austin, Texas, 78759.

The Journal of Texas Archeology and History.org is an organization dedicated to furthering research, education and public outreach in the fields of archeology and history concerning Texas and its bordering states of Louisiana, Arkansas, Oklahoma, New Mexico and Northern Mexico; a region we call the "Texas Borderlands." The J.T.A.H. is collaborating with the Index of Texas Archaeology and S.F.A.S.U. to distribute their publication library to the general public via free and open-access channels. Visit wWw.JTAH.org to submit an article. 


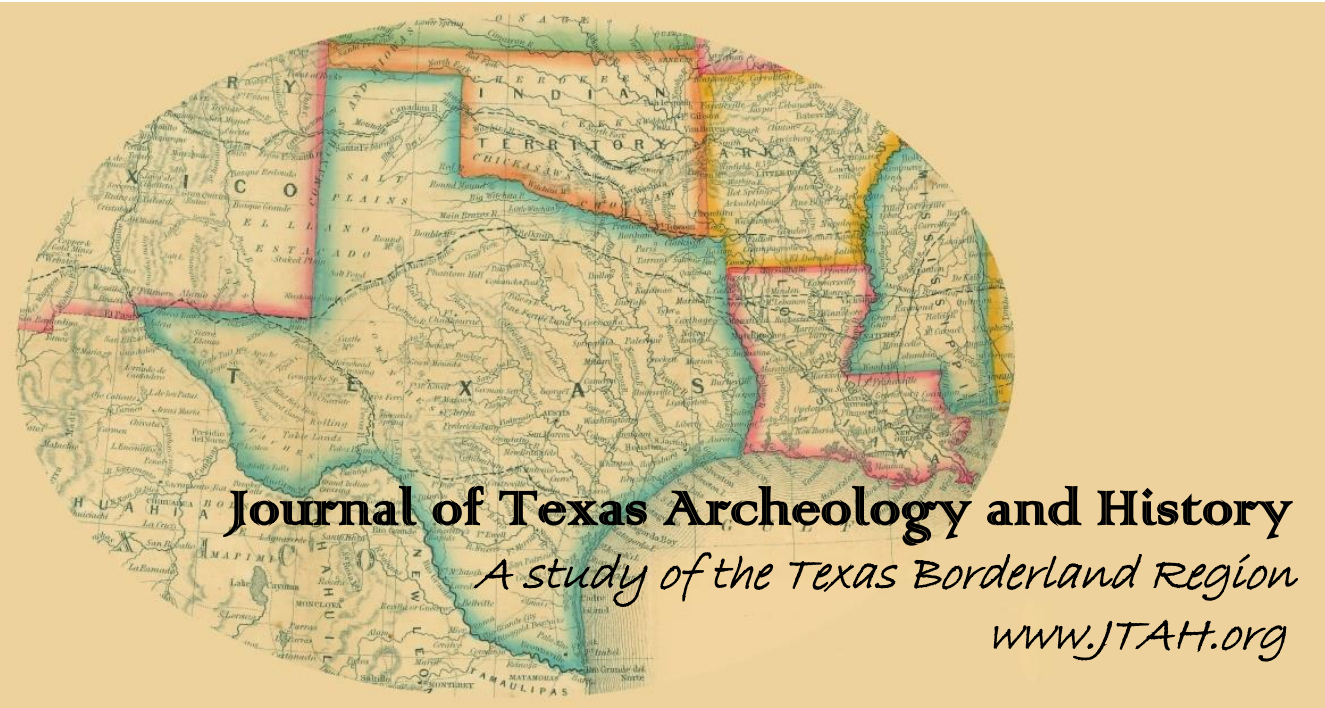

\title{
Article Title: FORGOTTEN SOLDIERS: BURIALS ON THE TEXAS FRONTIER AND SHIFTING PERCEPTIONS OF MILITARY INTERMENT
}

\author{
Author(s): $\quad$ Anthony Schienschang, Dept. of Anthropology, University of Virginia, Williamsburg, VA
}

Original Source: J.T.A.H. Volume 4 (2017/2018), Article 3, pp. 63 - 80; online 21 September 2018

Recommended Citation: Schienschang, Anthony; "Forgotten Soldiers: Burials on the Texas Frontier and Shifting Perceptions of Military Interment", (2018), Journal of Texas Archeology and History Volume 4 (2017/2018), pp. 63 - 80.

Copyright $(C 2018$ by Journal of Texas Archeology and History.org, Inc. All rights reserved. Online/Digital publication: ISSN 2334-1874

The online, digital, and print versions of the publication "Journal of Texas Archeology and History" are published by Journal of Texas Archeology and History.org, Inc., a Texas nonprofit IRC Section 501(c)(3) corporation.

Reproduction, posting, transmission, or other distribution or use of the Journal volume, individual article or any portion of the material therein, in any medium, is permitted strictly for personal, non-commercial purposes via a personal-use exemption under a Creative Commons license granted by JTAH.org, Inc. This license exemption requires, as a condition of its granted permission, proper credit be attributed to JTAH.org as copyright holder (e.g., Journal of Texas Archeology and History.org (C) 2018). No part of this publication may be reproduced, posted, transmitted, or otherwise utilized or distributed in any form by any means or method for commercial purposes without the express written consent of the Publisher. Inquiries should be addressed to JTAH Publisher, Suite 307, Box 361, 5114 Balcones Woods Drive, Austin, Texas, 78759.

The Journal of Texas Archeology and History.org is an organization dedicated to furthering research, education and public outreach in the fields of archeology and history concerning Texas and its bordering states of Louisiana, Arkansas, Oklahoma, New Mexico and Northern Mexico; a region we call the "Texas Borderlands." The J.T.A.H. is collaborating with the Index of Texas Archaeology and S.F.A.S.U. to distribute their publication library to the general public via free and open-access channels. Visit www.JTAH.org to submit an article. 


\title{
FORGOTTEN SOLDIERS: BURIALS ON THE TEXAS FRONTIER AND SHIFTING PERCEPTIONS OF MILITARY INTERMENT
}

\author{
Anthony Schienschang \\ Williamsburg, VA 23185 (anthony.schienschang@gmail.com)
}

\begin{abstract}
This research examines the interrelation between civilian and military burials on the Texas frontier in the 1850s with further discussion about the drivers for changing military burial practices. A soldier's life on the Texas frontier is briefly outlined along with some of the difficulties facing service members living in border forts. Special focus is placed on examining the socio-economic differences between officers and enlisted personnel, as well as the recording of deaths on the frontier. As a case study, the condition of the proposed location of the Fort Gates cemetery is explored and brief analysis of data gathered from the site is presented. The condition of the Fort Gates location is then compared to the nearby Sheridan Family Cemetery. The paper concludes by exploring how the American Civil War shifted civilian perceptions about military dead, leading to increased care for the remains of these deceased soldiers. Primary field research was conducted in Coryell County, Texas around the former site of Fort Gates, on the Fort Hood military installation, and in Gatesville, Texas.
\end{abstract}

\section{INTRODUCTION}

When Cain told God that he was not his brother's keeper, he was met with anger by God and told that the very ground cried out for his slain brother Abel (Book of Genesis, King James Version 2005). In the same way that Cain asked if he was his brother's keeper, Texans on the frontier in the 1850s were often callous about military burials. Though the ground may not have cried out in anger, from a modern American perspective, the negligent way soldiers were buried is almost unthinkable as it is a commonly held belief the United States always interred service members with care and dignity. This is not the case, however, as prior to the American Civil War active military and veterans were often not afforded any special recognition when interred.

For the average soldier on the Texas frontier in the 1850s, there were no illusions about the difficulties facing them while stationed at a border fort (Pugsley 2001). If a soldier were to die on the frontier, it was unlikely that their grave marker would survive for any appreciable amount of time. Perhaps more frustrating, burial records for soldiers from the time period are spotty at best and in many cases are non-existent. The limited contemporaneous written records that do exist are either military

\footnotetext{
JOURNAL OF TEXAS ARCHEOLOGY AND HISTORY

VOLUME 4:63-80

THE ONLINE PUBLICATION JOURNAL OF TEXAS ARCHEOLOGY AND HISTORY (ISSN 2334-1874)

IS PUBLISHED BY JOURNAL OF TEXAS ARCHEOLOGY AND HISTORY.ORG.

COPYRIGHT (C) 2018 JOURNAL OF TEXAS ARCHEOLOGY AND HISTORY.ORG. ALL RIGHTS RESERVED,
} 
diaries or letters kept by families to modern times. When these resources are not available, painstaking reconstruction must be undertaken by dedicated historians and archaeologists. Because of this lack of care and proper record keeping, many times soldiers were buried near border forts with little to mark their graves and without corresponding documentation.

There are numerous reasons why the graves of frontier soldiers may have been forgotten. War weariness after the Mexican-American War and the distance from the populous eastern part of the country are likely contributors. The perceived dangers posed by Native Americans also precluded families from traveling to retrieve the remains of their loved ones. The most significant contribution to the disparity between civilian and soldier burials on the Texas frontier was a result of the soldier's socioeconomic status, the ever-expanding nature of the western frontier, and a lack of roots in the area. A change in the level of care for military graves would not occur until after a cultural shift following the Civil War, serving to elevate the status of veterans in American culture.

\section{BORDER EXPANSION}

To understand the mindset of those on the Texas frontier in the mid-nineteenth century, knowledge of the Mexican-American War is essential. In 1845 the United States annexed the Republic of Texas, and granted the new territory statehood in December of that year. This annexation took place after the United States failed to purchase the area of Texas that had seceded from Mexico. President James Polk stationed federal troops in the new territory to secure it. The initial deployment of these troops was conservative, with the majority of the soldiers placed in the northern portion of Texas. With pressure from Washington, however, federal troops were moved further south towards the Mexican border (Pugsley 2001). This prompted the Mexican government to launch a preliminary strike against the American dragoons operating in the area. This action by the Mexican Army in April of 1846 killed 11 US soldiers and would later be known as the Thornton Affair.

The movement of American forces south was a deliberate provocation by the government of the United States to create public support for a declaration of war against Mexico. Following a relatively quick and bloodless campaign by nineteenth century standards, the conflict ended with the signing of the Treaty of Guadalupe Hidalgo in 1848 (Sandoval 2015). This treaty had the effect of establishing the southern border of the United States at the Rio Grande, and Mexico ceding land that would form the majority of the American West.

With the acquisition of this new territory, it fell to federal troops to provide security for thousands of square miles of unsettled land. Though state and territorial militia did exist, these soldiers were often less disciplined than federal troops and were more likely to commit criminal actions in the event of hostilities between Native American and settlers or against Mexico (Guardino 2014). Limited engagements between the militia and Native Americans did occur in the period between the MexicanAmerican War and the US Civil War; however, most operations were small, localized conflicts. The larger campaigns and Native American resettlement operations that took place in this period were the responsibility of the more disciplined and better trained federal troops. When not actively deployed on a campaign, federal soldiers manned a series of small forts along the edge of the Texas frontier. 
One reason for establishing a line of border forts was to protect settlers and travelers from hostile Native Americans. The government's and War Department's hardline stance was largely fueled by the pervasive institutional racism present at the time. Due to a long history of unfair deals, propaganda, and double-crossing between the two parties, it is easy to imagine the US-Native American relations by the offensive popular image of "savages out collecting scalps". This is an inaccurate understanding, however, as this period of border expansion was marked by relative quiet (Jones 2014).

Although there had been difficulties during the early years of the Republic of Texas, by the end of the Republic's existence relations between white settlers and Native Americans had cooled significantly due to proactive work by Sam Houston (Ginn 2011). During the Antebellum Era, it was not uncommon for members of the famed Texas Rangers to be of mixed Native American and Anglo descent (Ginn 2011). Peace along the frontier between settlers and Native Americans was generally the rule; yet to the average settler on what seemed to be the edge of civilization this may not have been of much comfort. It is interesting to note that the reaction and deployment of the United States Army at the time reflects this general attitude of peace. Had there been a much more significant threat posed by Native Americans, more resources would have been allocated to the frontier's defense. While they did respect their tracking, horsemanship, and hunting skills, commanders on the frontier often thought rather little of the local Native Americans as a legitimate military threat as the settler population increased (Pugsley 2001). This is likely due to the racist and classist undertones that pervaded the nineteenth century military.

The United States Army of the mid-nineteenth century was divided more sharply along class lines than it is today. At this point in the US Army's history, officers were generally educated, wealthy white males. Military service among this social stratum was not seen as a career or way to make a living, but rather a way to increase social status and prestige among their peers. This was due in no small part to the cost associated with being a commissioned officer; they were required supply their own uniforms, arms, and equipment. Being wealthy enough to provide their own equipment and afford top-of-the-line weaponry and other items was a form of bragging in its own right. This posturing may seem odd to modern sensibilities, to the gentry of the Victorian Era this conspicuous consumption was the norm.

Many men sought a commission out of a desire to serve their nation or because of other lofty romantic ideas. Men could also be commissioned based on what they could supply to a regiment. In several cases, commissions were handed out for furnishing horses or other supplies (S. Swafford to Family, letter, 15 May 1865, Private collection, Pikeville, Tennessee). The requirement for officers to furnish their own equipment made it difficult for anyone not well established in the country to obtain a commission. Because of their station and education, these men not only served as commanders, staff, and professionals but also acted as liaisons between local forts and nearby communities (Coker and Humphrey 1993).

Enlisted soldiers were in many cases the opposite of their commissioned counterparts. They were drawn from almost all walks of life and had varying levels of education and experience. Some were petty criminals who were offered the choice of enlisting or a jail sentence. Many were immigrants with little education and even less money. In the years before the American Civil War, an enlisted infantryman could make $\$ 7$ a month, with more being paid to artillery and cavalry counterparts (Smith 
1999). Unlike commissioned officers, enlisted men and noncommissioned officers were provided with weapons and supplies, significantly offsetting the cost of being a professional soldier. Unfortunately, the equipment was almost always second rate and not always available. Shortages in equipment and materials were often due to breakdowns in the military supply chain. In the case of both officers and enlisted personnel, housing and food were supplied when available; when it was not available, they were expected to build their own shelter and forage for food.

Being a soldier normally provided steady pay, but was not often a path to long-term financial success. The monthly pay of a soldier provided enough to meet a person's basic needs and allowed for some creature comforts; a luxury not often afforded contemporaneous factory workers. Serving in the military also provided the chance to travel beyond cities that were undergoing rapid and often unhealthy industrialization. These advantages, in addition to jingoistic and adventurous appeal, heavily contributed to recruitment among newly arrived immigrants. Military service provide tangible benefits to its members and was often a way to speed up the process of receiving citizenship for recent immigrants (Segal and Segal 2004). As many of these young men were sent to the United States ahead of the rest of their families, the benefits of citizenship and consistent pay were considerable.

While many of these newly minted citizens served their country admirably, they were often viewed as outsiders. However, native-born Americans were not much better off than their immigrant counterparts; being poor and uneducated was nearly as much of a hindrance to gaining social status as being an immigrant. African-American soldiers of the time were also worse off than immigrants; they were not allowed to serve as commissioned officers and were relegated to the so called "Colored Regiments". However, African-American interments did benefit from an established cultural framework in the United States. Lacking this framework, it is unsurprising that immigrant soldiers received little consideration for their remains at death. Due to an enlisted soldier's class and means, they often did not receive burials that conformed to accepted norms nor have their remains returned to their families if they died on the frontier.

\section{DEATH ON THE FRONTIER}

Life on the Texas frontier was difficult for a Federal soldier; though it did have a lower morality rate than other occupations due to the state-of-the-art healthcare available to soldiers at the time (Gerstle Smith 2013). A soldier on the frontier was far more likely to die from disease, in particular tuberculosis, than from a Native American raiding party. Interestingly, there does seem to be correlation between the rank of an individual and their susceptibility to disease. With officers being generally healthier, they suffered from diseases less often than their enlisted counterparts due to better diet and medical treatment (Steckel and Haurin 1994). Because of a lack of understanding of germ theory and disease propagation, hospitals and clinics on forts focused on the treatment of symptoms than on the prevention of disease.

Considered laughable today, these treatments included prescriptions of whiskey, arsenic, mercury, or bloodletting depending on how exactly the "humors" were imbalanced (Steckel and Haurin 1994). In the event that a soldier did not recover, they were either discharged or quarantined until they passed away. The act of quarantining a soldier and the conditions that they lived under saved more lives than 
prescriptions of whiskey and arsenic. The quarantined soldiers were kept under isolation and required to get a certain amount of fresh air and sunlight each day. By segregating the soldiers who were suffering from disease, many times the camp at large could be spared.

Sadly, sunlight and whiskey were often not enough to combat tuberculosis or the cholera outbreaks that periodically ravaged frontier forts. Upon their deaths, the incident was recorded and the soldier was buried (Steckel and Haurin 1994). The method of burial depended on the soil in which a soldier was buried. In the case of the frontier forts in Texas, soldiers were often placed in a shallow grave with a large stone slab covering the burial site. Because of the shallow rocky soil, graves on the Texas Frontier were rarely dug to the traditional six feet. Should the soldier be lucky enough to have a relative that could be contacted, the family of the soldier would be notified by the local commander. In the event that no relative could be located, a diary entry by the commander would often suffice to record the event.

It is in the burial of Antebellum, Texas frontier soldiers that discrepancies between modern interment practices of soldiers and those of the past occur. Today the National Cemetery Administration takes every effort to keep track of the names and locations of buried service members and this was not the case prior to the Civil War (United States Department of Veteran's Affairs, [USDVA] 2015). This is surprising because of the relatively few service members serving in the period after the Mexican-American War. Between the Mexican-American War and the US Civil War, the nation's military population was at its lowest point in nearly a century; $<0.01 \%$ of the national population was in the military during this period compared to just over 3\% during the American Civil War (Segal and Segal 2004). At this point career soldiers were almost unheard of, and the only service members who would have a chance of retiring from service were officers. It is almost counterintuitive that with fewer soldiers serving during the 1850s, record-keeping suffered. Considering the transient nature of the US frontier and its distance from the War Department in Washington, DC, it is reasonable to see how a communication breakdown could occur. This was especially true of smaller forts that only existed for a short period of time before being abandoned.

The forts established after the American victory in the Mexican-American War were planned as a series of north to south "lines" that proceeded from east to west as time and settlement occurred (Figure 1). Numerous forts existed but due to their distance from one another, relative inexperience of the soldiers with the land around the forts, and a limited number of troops, the forts never provided any real security beyond their limited spheres of influence. While the War Department intended for westward expansion to happen in an orderly fashion, the discovery of gold in California in 1849 precipitated the expansion of the frontier by hundreds of miles in a few short years (Wooster ca. 2000s). Because of this rapid expansion, the forts built along these lines would normally only be occupied for two to three years before the frontier expanded to the point where holding the land around the forts was no longer a military necessity. As the forts were abandoned, the soldiers who were buried at the forts were often forgotten as the Army moved west. The graves and markers normally fell into such states of disrepair that even local civilian populations could not remember the original locations of the cemeteries. 


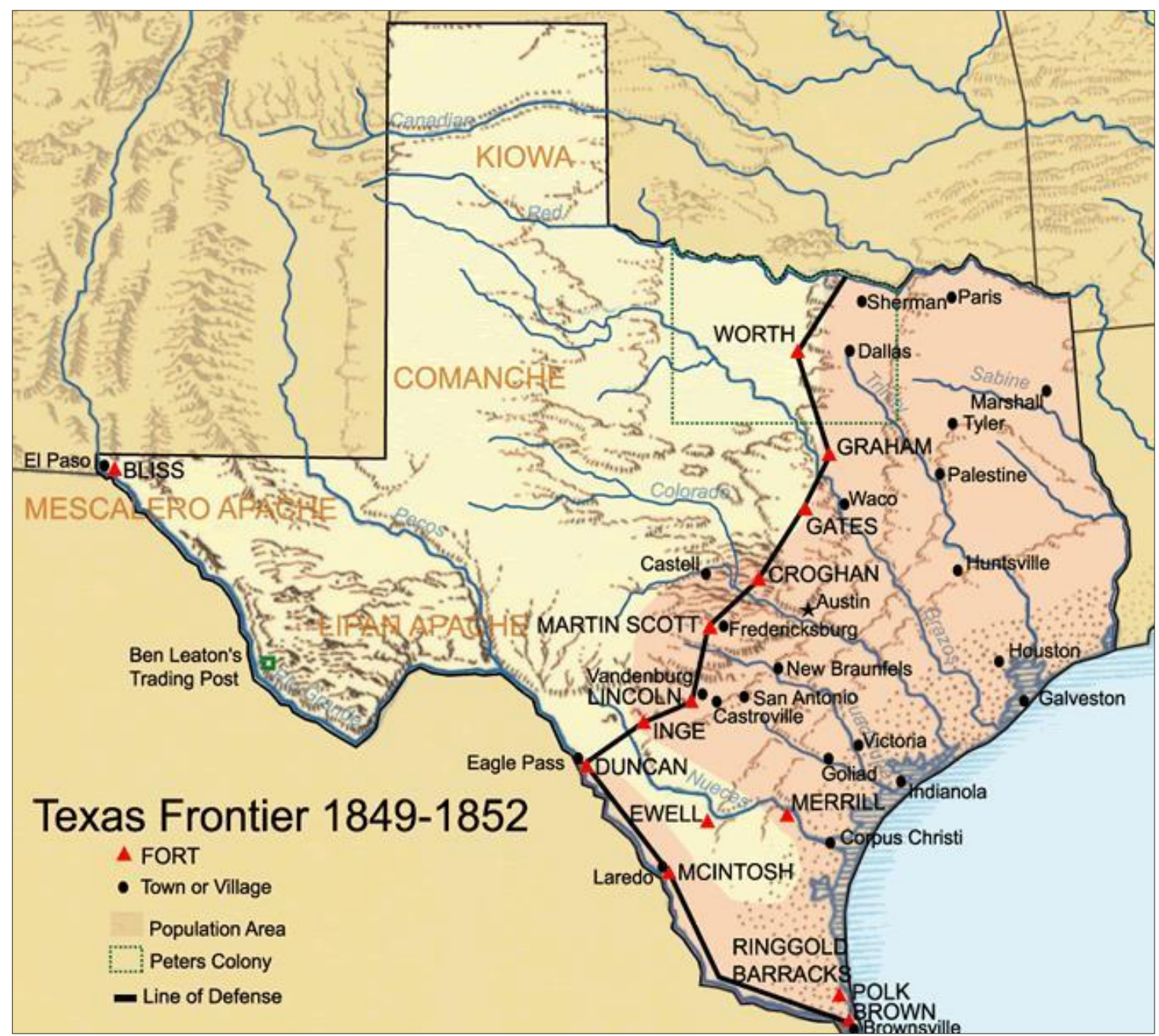

Figure 1. Texas Frontier Border Forts 1849-1852 (Wooster 2005).

\section{FORT GATES CEMETERY}

As one of the border forts along the line of the Texas frontier, Fort Gates serves as an excellent case study detailing how the location of soldiers' graves were forgotten following the abandonment of a fort. Operated for only three years, the fort was manned by the 8th US Infantry Regiment, who were charged to protect settlers against Native Americans. While the location of the fort is rather well known, the location of the soldier's cemetery was thought to be near the marker placed by the State of Texas. Recent research calls into question this assertion, and efforts were conducted to locate these graves (Miller and Sitters 2016). Using aerial photography, ground penetrating radar and magnetometers; exploration into the area around the location of the former Fort Gates provided data suggesting that the cemetery was not where the state marker proposed, but rather nearly $2 \mathrm{~km}$ to the southeast (Miller and Sitters 2016).

This location is marked by multiple stone features that are similar to contemporaneous grave markers used on the Texas frontier. Additionally, there are five magnetic anomalies that match the approximate dimensions and orientation indicative of a burial (Figure 2). The anomalies in Grid 4 are 
oriented east to west and measure approximately $2 \mathrm{~m}$ across by $1 \mathrm{~m}$ wide; these magnetic anomalies fit the dimensions of traditional Judeo-Christian burials. Each anomaly shows high magnetic susceptibility, a common feature of decomposed organic matter or human soil disturbances (Miller and Sitters 2016).

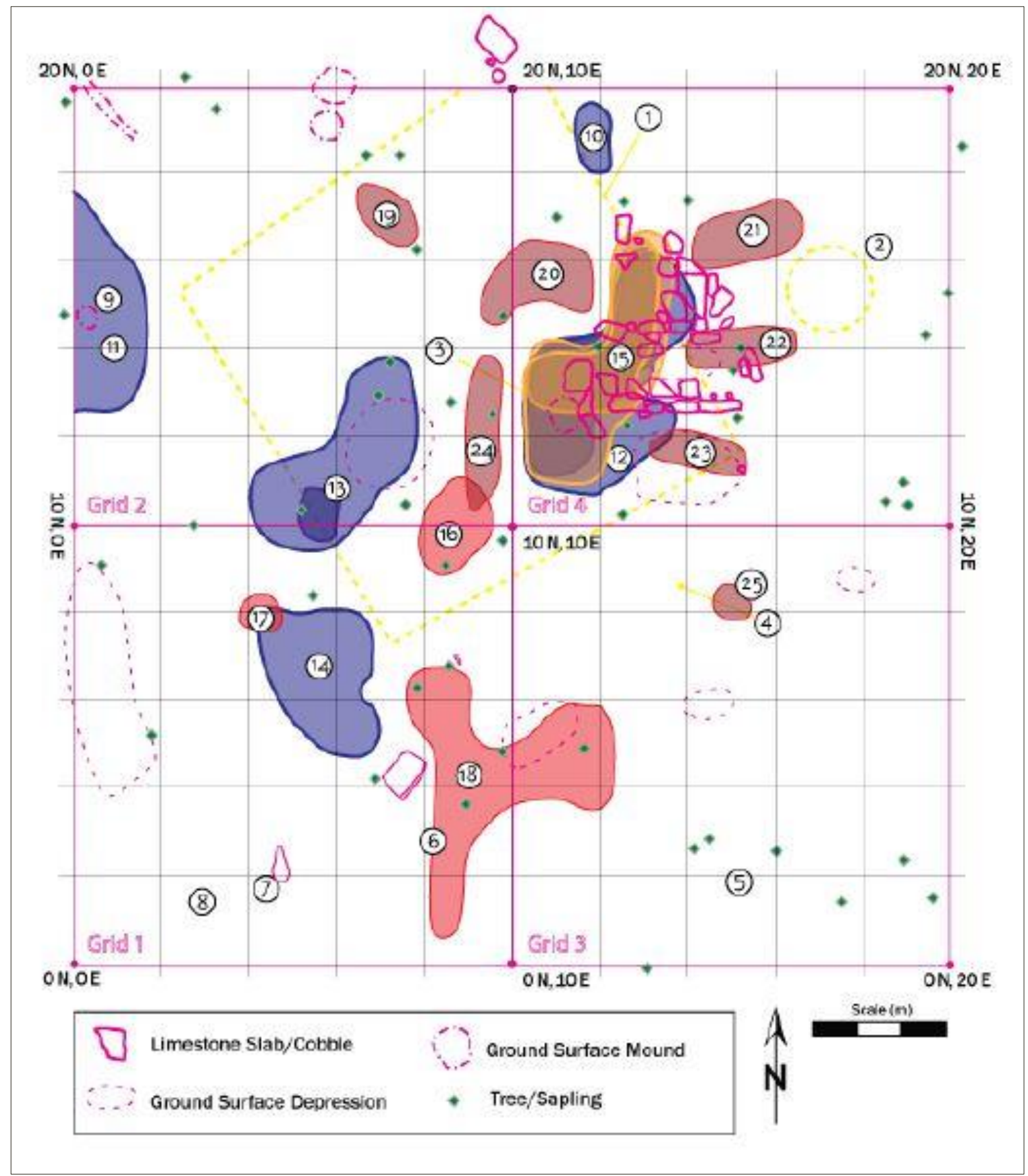

Figure 2. Summary of anomalies from the Fort Gates Cemetery survey (Miller and Sitters 2016).

The anomalies, numbered 19-23, are even spaced and located at a depth of approximately $150 \mathrm{~cm}$. This regularity suggests that the anomalies are manmade and not random underground voids or pockets of water. Furthermore, the anomalies are clustered around the largest collection stone that could 
indicate a burial (Figure 3). Unfortunately, the possible grave markers are in complete disarray and too worn for any signs of marking to be found, thus requiring further investigation. An additional anomaly that bears mention is anomaly number 24 ; this anomaly has a roughly north-south orientation and may be the grave of a criminal or other disgraced person. Based on the difficulty in establishing whether the site is in fact a cemetery, the Fort Gates cemetery has long been abandoned and fallen into extreme disrepair. Because of the social standing of the soldiers buried at Fort Gates, it is unsurprising that the cemetery's location was incorrectly recorded and neglected.

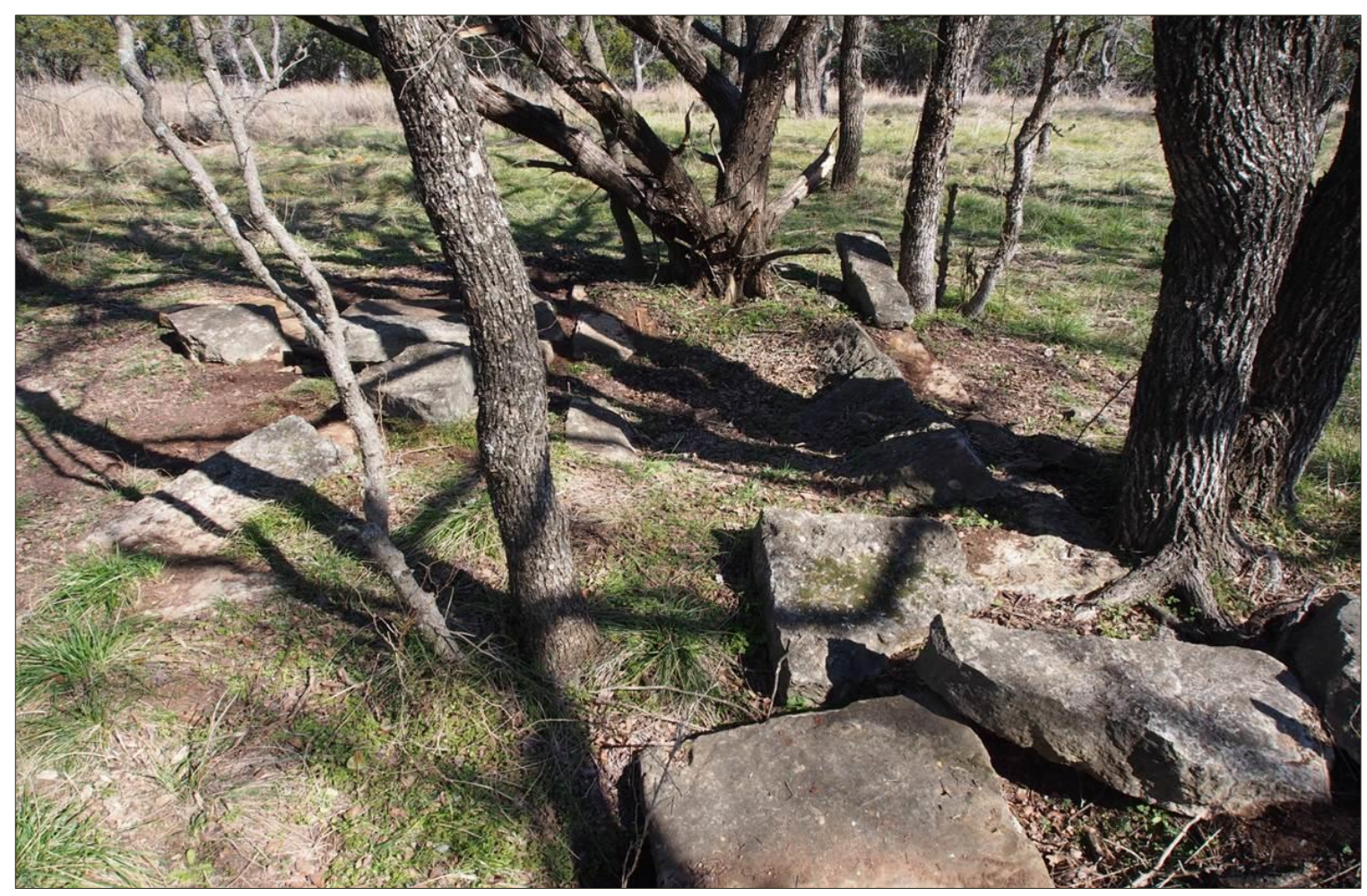

Figure 3. Possible deteriorated crypt feature from the proposed Fort Gates site.

Over the course of researching the possible Fort Gates soldier's cemetery, a site survey was also conducted of the nearby Sheridan Family Cemetery; this cemetery is nearly contemporaneous with the Fort Gates cemetery. The differences between the two cemeteries are quite drastic (Schienschang 2016). When identified, the location of the suspected Soldier's Cemetery was overgrown and potential inscriptions on the markers completely eroded. The civilian cemetery located less than $75 \mathrm{~m}$ away was relatively clear of vegetation and all the markers, while worn and eroded, are still legible. Some of the stone markers and features in the Sheridan Family Cemetery appeared to be similar in form to the stones found at the Fort Gates soldier's cemetery (Figure 4). The stones making up the burials at the Sheridan Cemetery were of similar dimensions to the large flat slabs of stone found at the Fort Gates Cemetery.

After cross referencing the names found on markers in the Sheridan Family Cemetery with Coryell County records, it became clear that descendants of the people interred at the cemetery continued living in the area for a long time. It is possible that familial descendants in the area maintained the Sheridan Family Cemetery graves up through the twenty-first century (USA, CRM cs. 2000s). This makes the relatively good condition of the Sheridan Family Cemetery unsurprising. Contrasted with the disrepair 
of the Fort Gates cemetery, it is obvious that there was no organization to care for the cemeteries of soldiers on the Texas frontier once a fort had been abandoned. Without having established themselves in an area, and with no organization to care for their graves, the soldier's cemeteries eventually eroded both physically and from local memory.



Figure 4. Crypt feature from nearby Sheridan Family Cemetery. Note the similar shape and dimensions of this crypt feature to the stone slabs at the Fort Gates site.

\section{TRANSIENT FRONTIER LIFE}

The Texas frontier was constantly expanding and a soldier would only be stationed at a location for a few short years before moving to the most recently established line of forts. From 1849 to 1860 , the location of the Texas frontier changed three separate times, occurring approximately once every 5 years (Wooster ca. 2000s). These shifts were not small changes of a few miles; in both cases of border expansion after 1849 the line of the frontier expanded hundreds of miles both west and north (Wooster ca. 2000s). As the frontier moved, the soldiers would move with the frontier, abandoning the previous forts and establishing new ones. Establishing new forts along the frontier was often the primary mission given to commanders by the War Department.

In addition to supporting the establishment of forts and the movement of the frontier, a soldier's normal duties would often preclude him from having the time to establish a family. Army regulations of the time prohibited enlisted men from marrying; officers faced no such restriction (Brown 2011). A soldier's normal duties around camp consisted mainly of maintenance and construction of defenses. Frontier forts along each line of defense were built and maintained almost entirely by the soldiers assigned to them. These forts were generally constructed of whatever materials were available locally; 
in most cases this meant earthworks and timbers. Between arrival and construction of more permanent lodging, enlisted men and officers would sleep in weatherproofed canvas tents. Stables and other buildings to support horses and livestock, a valuable commodity on the Texas frontier, were built before the soldiers' barracks for soldiers. Following construction of stables and livestock buildings, storehouses and other logistical buildings were erected (Baker 2012). Frontier forts were considered transient in nature and simultaneously expected to fully serve the purpose of defending the frontier. During its tenure, Fort Gates eventually encompassed 17 permanent structures. A fort of this size was usually not constructed solely of nearby materials, some building materials were brought with the army when they moved to establish a new fort. When a water route was unavailable, larger building supplies had to be transported overland, often with great difficulty.

Generally, however, it was up to the soldiers assigned to these forts to make the supplies needed for their construction. If the soldiers could not fabricate the materials themselves, as was often the case for items such as construction nails and large metal fixtures, commanders could do business with the settlements that often sprung up near these forts. This had the twofold effect of stimulating the local economy and establishing friendly relations with the nearby settlements. Though the work was difficult, it provided a break to the monotony that could set-in around less exciting locations.

The other primary duty of soldiers on the frontier was to conduct drills to enhance military readiness. Of course, military readiness was a bit of a misnomer because forts were severely understaffed. Had the forts been fully manned, they still would have lacked the manpower to effectively patrol the hundreds of square miles under their control. Still, the soldiers needed to perform basic military tasks which included activities away from the fort. When not in camp, a soldier could be expected to conduct reconnaissance patrols against Native Americans and protect traders and settlers on their way to California (Wooster ca. 2000s).

Though these postings along the trails and scouting Native Americans were exciting, they left little time for a family, even among officers. By constantly doing hard labor and being away from the forts and small communities that sprung up around them, soldiers were unable to put down lasting roots in an area. With no local family support, when the inevitable deaths occurred, it is unlikely that many of these men's graves were marked or documented in any way beyond local diaries of commanding officers. When the graves of soldiers were recorded and marked, it was normally because they were not buried by comrades, rather they were buried with their family and the record annotated that they were veterans. This generally only occurred if a soldier left the service near a military installation on the frontier and started a family, as was the case with several of the men who served at Fort Gates (Coryell County, TX 2008).

One notable exception is for the graves that have fallen under control of the federal government, particularly on military installations that have expanded over the last 150 years. Through careful crossreferencing of available records, Fort Hood's cultural resource management team has been able to identify some of the previously unknown graves. In cases where the graves could be identified, their locations are marked and fenced off to prevent tampering. These locations are then regularly maintained and can be visited by researchers and the public (Figure 5). Maintenance of the existing cemetery by Fort Hood has led to some relatively well preserved grave markers for individuals from this time period, 
soldier and civilian alike (Figure 6). In some cases, these graves contain the remains of service members who served in the Civil War. These veterans settled in the area and spent the remainder of their lives as members of local communities.

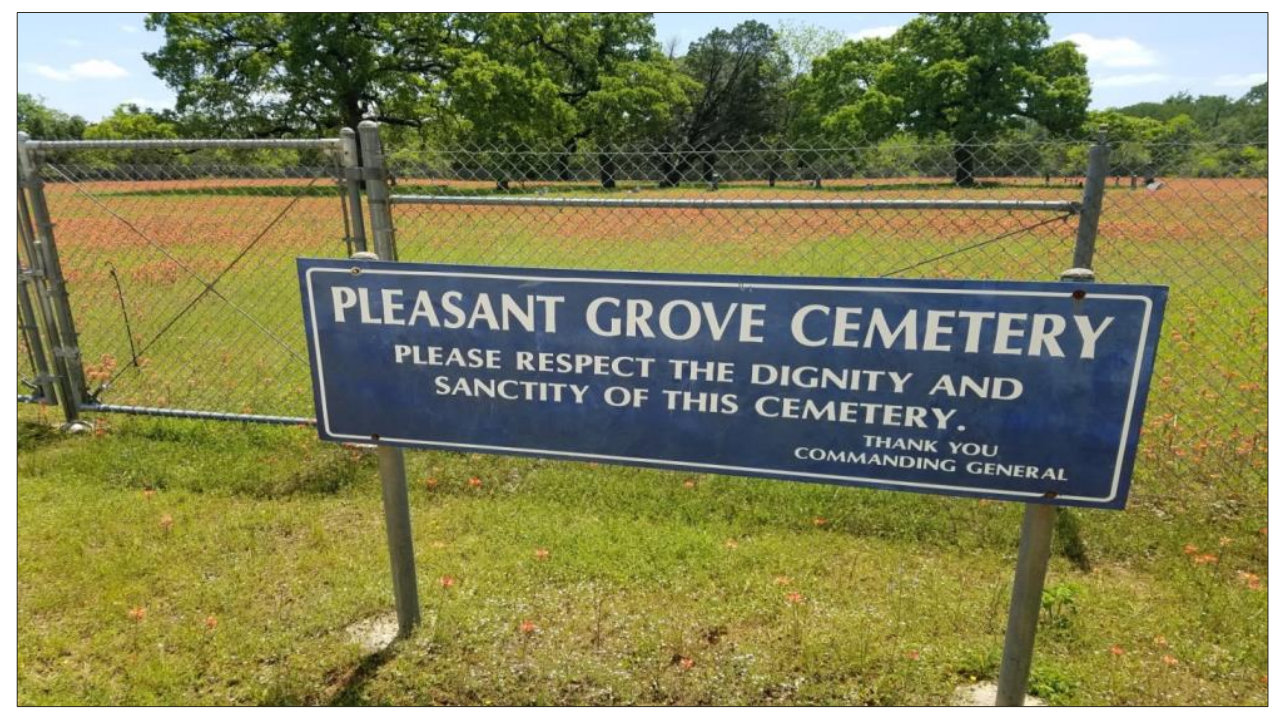

Figure 5. Pleasant Grove Cemetery located near the possible Fort Gates Soldier's Cemetery and Sheridan Family Cemetery. This cemetery is maintained by the federal government.



Figure 6. Relatively well preserved grave marker of John Cummings at the Pleasant Grove Cemetery located on Fort Hood, Texas. Because John Cummings settled in the area and established roots, his marker is still legible. 
There is evidence to suggest that many soldiers completing their tour of duty elected to remain near their previous fort, as opposed to returning to the place of their enlistment. At Fort Gates, many of the original surrounding small communities were led by veterans, which would eventually become incorporated into Gatesville, Texas (USA, CRM ca. 2000s). This can be extrapolated from records of the soldiers that served at Fort Gates compared to those that initially settled in the area around Fort Gates after the post was abandoned. This decision to remain near the forts is likely due to the arduous journey that returning east would entail (Gerstle Smith 2013). Even the relatively easy journey by boat to the east coast could take as long as a month if the ship met with good conditions (Dixon 2014). The journey overland could take twice as long and would be considerably more difficult. It was likely much safer to risk life on the frontier than to undertake the journey of several hundred miles over largely untamed land or the expensive journey by sea. Once these soldiers settled on the land and began raising families, their legacies were less likely to be forgotten. This stands in contrast to the unknown soldiers who died while in service and were buried with no loved ones near them.

\section{SHIFTING PERCEPTIONS OF MILITARY BURIALS}

The disparity between soldier and civilian graves raises the question as to when the shift towards record-keeping and accountability took place. The American Civil War was the main galvanizing factor that caused the public to take notice of the burial of their military dead (USDVA 2015). The scale of death that the average American witnessed during the Civil War was unprecedented in the nation's history until that point. Previous military encounters had either occurred in a distant place, such as the Mexican-American War, or in a relatively limited area such as in the War of 1812. Violent death due to warfare was far from the norm at this point in North America. Soldiers on the frontier aside, the average person could reasonably expect to live and die a proper death (Faust ca. 2010s). A proper death in this case meant dying of illness or old age; violent or accidental deaths were much more shocking and undignified. The wholesale carnage of the US Civil War shocked the nation into reconsidering its treatment of those who died fighting to defend it.

The American Civil War was the deadliest conflict in the nation's history; conservative estimates of military dead are around 620,000 (Faust ca. 2010s). More American soldiers died during the Civil War than all other US wars combined. The military dead accounted for $2 \%$ of the population of the United States at the time; compared to today's population, this is equivalent to 6 million soldiers being killed today. Civilian deaths directly attributable to the war approached an additional 50,000. Proportionately, the Confederacy suffered considerably more devastation than the Union. In Europe, the only area that experienced similar levels of civilian casualties was Central Europe during the Second World War (Faust ca. 2010s). Popular opinion at the time was that nearly every household had some member killed in the war. Whether killed by enemy action on the battlefield or disease, service members and civilians were killed in droves.

Death now became something that most people witnessed either first hand or through the loss of a loved one. The average person in the 1800s was more accustomed to dealing with death than their twentieth century counterparts. High infant mortality rates, death in childbirth, and the slaughter of animals at home for food were relatively commonplace occurrences. Combat deaths, however, were a 
new experience for most of the country's population and took a much different toll on the nation's culture and psyche. Instead of death being at the end of a long life, people were being slaughtered in the prime of their lives. To the Victorian Era mind, this often shocked the sensibilities, especially among the upper class. In many cases, these lives were wasted; thousands killed for relatively minor tactical gain.

It is important to remember however, that large scale death due to war was far from a foreign idea at the time. Largely insulated from the brutal nationalist and civil wars that had ravaged Europe, Americans were unaccustomed to seeing heaping mounds of their fellow citizens and loved ones. The reason that the Civil War had such an impact on the psyche and culture of the United States was because it brought war to the people's doorsteps. New technology only added to the mortality rates of Civil War battles. Gone were the days of the single shot musket, soldiers on the battlefields of the Civil War fielded the latest in military technology including lever action rifles, accurate artillery, and machine guns (Hacker 1993). Just as manufacturing was becoming systematic and industrialized, so too did warfare.

Though warfare was becoming dehumanized and machine-like, there still existed a strong emotional attachment to the dead. These emotions were not limited to the families who had lost loved ones, but were also shared by comrades and in some cases, their enemies. Because of this new intimacy with combat deaths and emotional attachment to the dead, efforts were made by volunteers to respectfully bury the thousands of dead that littered the numerous battlefields. In the case of the Battle of Antietam, 23,000 dead covered the battlefield after one day. Due to the sheer scale of removing the remains, many times the bodies would remain on the battlefield for days (Figure 7). In the



Figure 7. Bodies of soldiers killed at Marye's Heights during the Battle of Fredericksburg in 1863 (Library of Congress 1863).

words of one Union surgeon, "the dead were almost wholly unburied, and the stench arising from it was such as to breed a pestilence" (Faust ca. 2010s). When the dead were finally buried it was not done from a solely humanitarian perspective; disposing of the bodies was a matter of public health.

Though the general public did not have a firm grasp on the causes of disease, they did understand that leaving thousands of dead uncovered would lead to unsanitary and less than pleasant conditions. If the remains of the dead were not collected, scavengers could be expected to descend upon the veritable feast that remained. Interestingly, the term scavenger does not only apply to animals, but also to opportunistic individuals looking to loot the bodies of the fallen. This was not necessarily done with criminal intent or for profit. At times, looting was the best way for victorious soldiers to resupply after a hard won fight (Turner 1990). Severe material shortages suffered by soldiers in the Civil War, especially those of the Confederacy, meant that many times picking up a discarded weapon was a more 
reliable way to upgrade a soldier's equipment. Not only did this solve the immediate issue of resupply, it also did not further tax an already stretched supply-chain.

Eager to prevent scavengers from descending upon their property, land owners were quick to remove the bodies. In most cases, these dead were simply dumped into mass graves with a marker indicating the fallen regiment and affiliation if known. Little care was given to the preservation of these bodies; the main goal was to cover them as quickly as possible. In the Confederacy, these bodies were normally collected and buried by African-American slaves. For battlefields in Union controlled territory, corpses were collected and buried by soldiers or the poor (Figure 8). These mass graves posed numerous problems of identification,

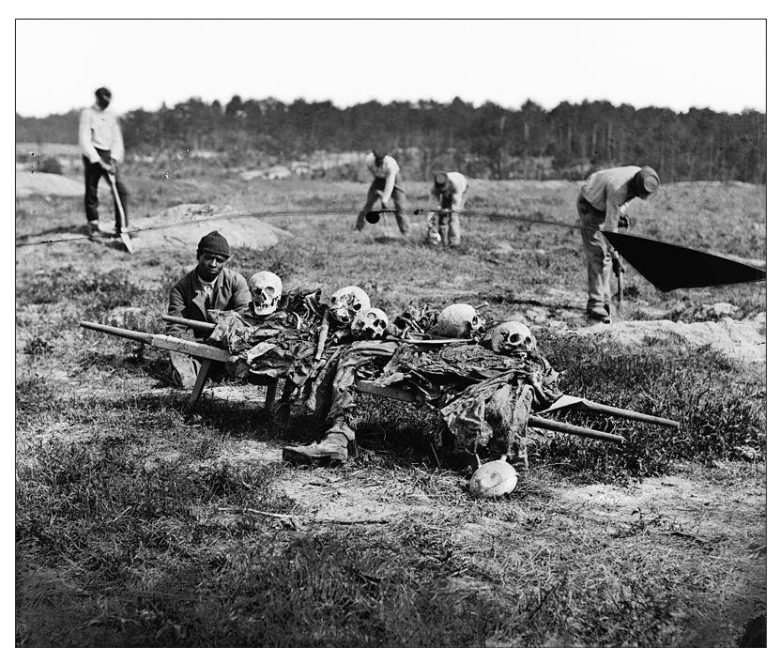

Figure 8. African Americans remove bodies near Cold Harbor (Library of Congress 1865). especially in the case of enemy dead, as these soldiers were less likely to receive special treatment.

Adding to the difficulty that mass graves presented, soldiers rarely carried anything in the way of identification, unless that person were an officer or someone of importance. The closest thing to identification issued to soldiers were their uniforms and equipment; the uniforms of certain branches were marked with different colored trim or unit specific buttons. Those soldiers that were concerned with the identification of their remains in the event of their death commissioned personalized metal tags with their names and other information stamped or engraved on the surface. These pieces of metal were worn on either the wrist or neck and secured with a chain or length of cord. Eventually, the War Department would adopt this idea into identification tags, now more commonly known as "dog tags". For those soldiers who could not afford to purchase these identification tags, some would take care to write their name clearly on a piece of paper and then pin it to the inside of their uniforms.

\section{IDENTIFYING BATTLEFIELD REMAINS}

Whether a public health issue or a humanitarian effort, attempts were made to identify remains to the best of a volunteer's ability. While commendable, these efforts lacked any clear organization and, in most cases, were simply groups of family members looking for their loved ones (Faust ca. 2010s). These burial expeditions were often funded at great cost by the families of soldiers who operated on information sent by survivors of the battles, if they could be reached at all. Because of this expense, it generally precluded families of lower economic means from ever learning about the ultimate fate of their family members. Several charities and organizations were established to assist with the identification of remains. Even with the support of these charities, the task of recording the dead in field hospitals and across battlefields was daunting. Without any centralized record-keeping agency, this 
documentation was notoriously difficult to sort through (Faust ca. 2010s). If a family was fortunate to receive a letter stating that their loved one had been killed, this tended to be the exception to the rule.

While it was possible for bereaved families to receive a letter about their loved one, it is unlikely that they would be able to leave their farms or factories to sort through thousands of bodies to identify their fallen family member. If a family had not heard from their loved ones in several months, and knew that their love one's regiment had been in combat, families could piece together the likely location of death through tracking the movement of armies via the press and rumor. Of course, this piecemeal effort was difficult in its own right as the press was considerably less reliable than today.

\section{FEDERAL GOVERNMENT RESPONSE}

In response to this disorganization, the United States Congress began the process of creating a new organization to standardize the interment of military remains (USDVA 2015). Due to the disjointed nature of American politics it would be several decades after the end of the Civil War before a unified government organization was established. Eventually, the National Cemetery Administration, which would later become a part of the Department of Veteran's Affairs, was created in the 1870s. With the creation of the National Cemetery Administration, several national cemeteries were designated along with the criteria needed for interment in them (National Cemetery Administration 2015). While the initial criteria for interment was not broad enough to allow any veteran to be buried, it did provide a baseline which would later be expanded over the next 150 years.

The effort to identify remains led to a significant increase in the number of Civil War soldiers being identified. Generally, after being exhumed from mass graves, bodies were later interred in a private or newly established national cemetery (Faust ca. 2010s). Though there was a significant increase in the number of those buried, to date nearly half of the Civil War remains reinterred are unidentified. When buried at private cemeteries, bodies were often marked with the unit, campaign, and affiliation of the deceased service member. While the information on these markers is at times unreliable and not always easy to corroborate, it does have value as it is often the only source of tracking where military members settled after their tours were complete. Marking graves had the twofold effect of providing closure to the families of Civil War veterans, and helping a broken nation process the violence that had affected so many of its people.

\section{DISCUSSION}

Identification of Civil War remains helps to address the issue of a respectful burial for soldiers from that period; however, it does very little for the remains of service members who died in the years before the Civil War. Despite the need to identify these remains, there is little interest in the work needed to catalog and record these sites. This could be because of the lack of general public knowledge of the

period or simply because it is not as romantic as the American Civil War that followed soon after. This is unfortunate; if the graves of the soldiers could be identified and documented, there are several programs through the Nation Cemetery Administration that would allow individuals to either be reinterred at a national cemetery or to have their graves appropriately marked. 
With the cultural change in American treatment of military dead, the disparity between pre-Civil War graves and post-Civil War graves seems out of place. In little over a decade, there is a shift between soldiers dying unremembered on the frontier to efforts to identify and record as many soldiers as possible who died in service to the country. The temporal proximity of frontier burials to the Civil War is one possible explanation of why the soldiers buried on the Texas frontier were largely forgotten.

The life and death of soldiers on the frontier were overlooked because of the sheer violence of the Civil War a few short years later. This overshadowing was not the first, nor sadly last, time that such an event has happened. A strong argument could be made for the role of reporting and other media on the perception of these more well-known conflicts, as well as the differences in time devoted to education on the subjects. Even with differences in cultural impact however, finding the gravesites and documenting the experiences of individuals in less culturally impactful conflicts still holds value.

Uncovering burial locations of soldiers on the Texas frontier is an important task in better understanding frontier military life. Though these men were of low socio-economic class, and perhaps not valued during their lifetimes, they are still an important part of American history. Through their eyes, the American West was fought for and won, however poorly public opinion may look back on both the means and end. By making the effort to reconstruct their lives through the location of their graves, exhumation, and material culture analysis, important insights can be gained about their health, priorities, and beliefs.

Looking forward, modern record keeping is considerably better than that of the Texas Frontier and Civil War; however, if a large-scale war breaks out it is likely that the remains of many service members will be unidentified. The idea that it is possible to catalogue the deaths and the locations of remains for every person killed in action during a large-scale war is folly. While officers and important individuals who die during important battles will be studied, those of lesser standing and smaller battles will likely not be. This is especially true if they are from a race or socio-economic group that is not in favor or that is underrepresented in the nation. If this happens, these people will become the new lost and forgotten.

\section{REFERENCES CITED}

Baker, James Graham.

2012 Seth Eastman's Drawing of Corpus Christi: A Military Man's Representation of the South Texas Frontier Settlement, Circa 1849. Southwestern Historical Quarterly 116:168-181.

Brown, John Sloan.

2011 Kevlar Legions: The Transformation of the United States Army 1989-2005. Center of Military History - United States Army. Washington, DC.

Coker, Caleb and Janet G. Humphrey.

1993 The Texas Frontier in 1850: Dr. Ebenezer Swift and the View from Fort Martin Scott. Southwestern Historical Quarterly 96:393-413. 


\section{Coryell County, Texas}

2008 Fort Hood Moved Cemeteries. USGENWEB: Compiled by Fort Hood Cultural Resource Management. Electronic document, http://files.usgwarchives.net/tx/coryell/cemeteries/fthoodmoved2.txt accessed June 11, 2016.

Dixon, Ann.

2014 Letters from Texas: An Army Wife on the Texas Frontier 1856-1860. Journal of Big Bend Studies 26:181.

Faust, Drew G.

2010 Death and Dying. Article Database. National Park Service, Electronic document, https://www.nps.gov/nr/travel/national_cemeteries/death.html accessed July 1, 2016.

Gerstle Smith, Donna.

2013 Till Death (or Discharge) Do Us Part: The State of Medicine at the Nineteenth Century U.S. Army Post of Fort Davis, Texas. Journal of Big Bend Studies 25:105-117.

Ginn, Jody Edward.

2011 Review of Savage Frontier: Rangers, Riflemen, and Indian Wars in Texas, 1842-1845, vol. 4. Southwestern Historical Quarterly 115:218.

Guardino, Peter.

2014 Gender, Soldiering, and Citizenship in the Mexican-American War of 1846-1848. American Historical Review 119(1):23-46.

Hacker, Barton C.

1993 Engineering a New Order: Military Institutions, Technical Education, and the Rise of the Industrial State. The John Hopkins University Press. Baltimore, Maryland. Electronic document, http://www.jstor.org/stable/3106453 accessed July 12, 2016.

United States Department of Veteran's Affairs (USDVA)

2015 History and Development of the National Cemetery Administration. Washington, DC. Electronic document, https://www.va.gov/about_va/vahistory.asp accessed July 23, 2016.

Jones, Richard S.

2014 Post of Lampasas: Forgotten Reconstruction Era U.S. Army Post (1867-1870). Journal of Texas Archaeology and History, 2:27-30. Electronic document, https://drive.google.com/file/d/0B4p1SsI5fon7NHBGa1MtRWFpYWs/view accessed August 1, 2016.

Library of Congress

1865 Cold Harbor, Va. African Americans Collecting Bones of Soldiers Killed in the Battle. Washington, DC. Photograph, http://www.loc.gov/pictures/item/cwp2003000494/PP/ 
Library of Congress

1863 Stone wall at foot of Marye's Heights, Fredericksburg, Va. at the front carried by 6th Maine Infantry, May 3, 1863. Photographed twenty minutes after storming party had [...] up the hill. Washington, DC. Photograph, http://www.loc.gov/pictures/item/2012647842/

Miller, Mason D., and Julian A. Sitters.

2016 A Multi-Methodological Geophysical Survey of the Possible Fort Gates Cemetery Site, Gatesville, Coryell County, Texas. Report on file at AmaTerra Environmental. Austin, Texas.

National Cemetery Administration.

2015 General History. Department of Veteran's Affairs. Electronic document, https://www.cem.va.gov/CEM/history/history.asp accessed July 23, 2016.

Pugsley, William S.

2001 Imprint on the Land: Life Before Camp Hood, 1820-1942. United States Army. Fort Hood, Texas

Sandoval, David A.

2015 The American Invasion of New Mexico and Mexican Merchants. Wagon Tracks 29(3):1417. Santa Fe Trail Association. Albuquerque, New Mexico

Segal, David R., and Mady Wechsler Segal.

2004 America's Military Population. Population Reference Bureau 59(4):4-5

Schienschang, Anthony.

2016 Not My Brother's Keeper: Forgotten Soldiers of the Texas Frontier. Presentation to Texas A\&M University Central Texas 2016 Historical Archaeology Class. Killeen, Texas

Steckel, Richard H., and Donald Haurin.

1994 Health and Nutrition in the American Midwest: Evidence from the Height of Ohio National Guardsman 1850-1910. Stature, Living Standards and Economic Development. pp. 117-128.

University Press of Chicago, Chicago, Illinois

Smith, Thomas T.

1999 The U.S. Army and the Texas Frontier Economy, 1845-1900. Texas A\&M University Press, College Station, Texas.

Turner, Rory.

1990 Bloodless Battles: The Civil War Reenacted. TDR (1988-). 34(4):123-36.

Wooster, Robert.

2005 U.S. Army on the Texas Frontier. Texas Beyond History: Frontier Forts. The University of Texas at Austin. Austin, Texas Electronic document, https://www.texasbeyondhistory.net/forts/military.html accessed July 23, 2016. 